\title{
Theatrical Art in Classical European and Modern Arabic Literature:
}

\section{(A Comparative Approach)}

\author{
Salahuddin Mohd Shamsuddin ${ }^{1} \&$ Siti Sara Binti Hj. Ahmad ${ }^{1}$ \\ ${ }^{1}$ Faculty of Arabic Language, Islamic University Sultan Sharif Ali, Brunei Darussalam \\ Correspondence: Prof. Dr. Salahuddin Mohd Shamsuddin, Simpang 347, Jalan Pasar Baharu. Gadong BE 1310. \\ Brunei Darussalam. Tel: 67-836-4851. E-Mail: shamsuddinsalahuddin@gmail.com
}

Received: May 1, 2018; Accepted: May 13, 2018; Published: June 14, 2018

\begin{abstract}
No doubt that Classical Arabic Literature was influenced by Greek Literature, as the modern Arabic literature was influenced by European Literature. The narrative poetry was designed for the emergence of theatrical poetry, a poetry modeled on the model of the story with its performance in the front of audience. This style was not known as Arabic poetry, but borrowed from the European literatures by the elite of poets who were influenced by European literatures looking forward to renew the Arabic poetry. It means that we use in this article the historical methodology based on the historical relation between European and Arabic literature in the ancient and modern age.

The first who introduced the theatrical art in Arab countries was Mārūn al-Niqqāsh, who was of a Lebanese origin. He traveled to Italy in 1846 and quoted it from there. The first play he presented to the Arab audience in Lebanon was (Miser) composed by the French writer Molière, in late 1847.

It is true that the art of play in Arabic literature at first was influenced by European literatures, but soon after reached the stage of rooting, then the artistic creativity began to emerge, which was far away from the simulation and tradition.

It is true also that European musical theatres had been influenced later by Arabic literature and oriental literatures. European musical theatres ('Alā' al-Dīn and the magical lamp), the play (Mā' rūf Iska in Cairo) and the musical plays of (Shahrzād) are derived from (One thousand and one Nights).

This study aims to discover the originality of theatrical art in modern Arabic literature. Therefore it is focused on its both side: Its European originality and its journey to Arab World, hence its artistic characteristics in modern Arabic literature. We also highlight its journey from the poetic language to the prose.
\end{abstract}

Keywords: theatrical art, origins of theater, classical era, theaters in European literature, English romantic theaters, theaters in modern Arabic literature

\section{Brief Background of Classical Era}

Classicism is the first and oldest literary doctrine originated in Europe after the movement of scientific renaissance that began in the fifteenth century AD. It is known that the basis of that renaissance was the restoration of ancient Greek and Latin culture and literature. Although the pioneers of this restoration appeared in Italy, where the scientists and writers of Byzantine or Constantinople first came into the hands of the Turks, but France was the true cradle of the classicism or the soil in which it grew. This is because the French people considered themselves the true heirs of Attica: The province where Athens is located, where the eyes of Greek literature and thought have appeared. French are still proud of being the inheritors of that Attic spirit characterized by a special spirit, which is still known as the Attic spirit.

Classicism in its linguistic meaning derived from the Latin word "Classis" and its original meaning was the military or naval fleet or (the unit in the fleet or absolute unit) and then it was used for a unit of study i.e. (Classroom) and the word Classicism was taken from this latter meaning, i.e. school literature in the sense that it was the literature which escaped the flood of time and remained alive, and it had a quality that made it the means of education in the classrooms, as the brain and emotions could be cultivated and softened by its reading. 
Hence, the classicism has multiple meanings, especially these two meanings:

1. When this word is used as a sentence to judge a literary book, it is said that it is a classical book or a classical novel, in the sense that it is a good book to be used in the education of young students.

2. The conventional meaning of a particular type of the literature appeared in the seventeenth century in France - in particular - and this literature has some features and characteristics that we want to talk about them.

So the classical literature means the literature prevailed in the seventeenth century, had the following features:

1) It inspires from Ancient Latin and Greek literature and derives its material.

2) It is a literature issued by the mind and governs the reasoning, and the most important quality of the mind is the moderation and clarity.

3) Careful formulation and refinement of the style.

It follows some assets and rules collected by French critic (Boileau) in a poem called (Art of the poetry) simulating a Latin poet Horace in his book: (Arts Poetrica). (Muhammad, 1962, P. 376)

\section{Introduction}

The play had been originated from the lyric poetry. The satire and interjection of the insults was an individual issue, in which the poet meant to insult a certain person, then rose to be used as a collective poetry, in which the poet addresses the deficiency or laughing of deficiencies generally, and then the comedy arose. (Aristotle, 1962, $\mathrm{p}$ 160) The comedy was the highest level of the satire, because it had a social nature, as its origin was related in the beginning to the songs of fun and pleasure that Greeks used to sing in the festivals of their gods, especially, Dionysus God of the fertility, development and fun. Also, the tragedy was a development of poems of praise, as it had a religious character. It is originally due to the religious songs that were chanted by a chorus at the festivals of Dionysus to celebrate the attributes of that god, and then the praise of the other heroes were added to those songs that gradually obtained the theatrical character. (Sir Paul Harvey, 1989)

It was originally based on the lyrical character of the chorus. Aristotle was the first to point out that the chorus had no theatrical character except if it was related to the event. (Muhammad, 1962, B. Line: 9-15).

The play is different to the story of epic and it depends on the dialogue, the act or the event essentially, but it is like the story includes the incident, the character, the idea and the expression. Its manner of using the dialogue mainly distinguishes it clearly from the story, therefore, the dialogue is its only tool for imaging. Dialogue is the outer appearance of the sensory play. Its moral appearance is the strife. The word (drama) deals with an internal strife. The theatrical art has been characterized by two features: Dialogue and conflict. The play cannot be put on its real artistic place, but only if it is represented on the stage. Therefore, this theory originally, calls to the relation between the drama and theater, and the actors and spectators.

The play originated in ancient Greek literature, and was divided into comedy and tragedy. We know by the study of history of the play in the Greek literature that it is originated from the village celebrations, which were held in ancient Athens to God of the nature (Dionysus).

The most famous authors of the tragedy in the ancient Greek literature were three characters: Sophocles (died 405 BC) Euripides (died 406 BC) Aeschylus the "Father of Tragedy", (died 456 BC), and the most famous author of the comedy in the ancient Greek literature was Aristophanes (died 387 BC). He was the author of the famous comedy: (Frogs).

When Latin learned Greek theater followed it imitating all of its technical characteristics. Latin theater grew up in the middle of the third century BC nearly, as the technical templates were fully followed by Latin. One of Greek figures was Blots (died: in $184 \mathrm{BC}$ ). He was one of the writers of comedy, and Seneca was one of the writers of the tragedy.

When the European revival movement began in the fifteenth century, the Europeans returned to the ancient Greek and Latin literature, following the plays of Greeks and Romanians, but they gathered in the play between the singing, dancing and dialogue; but this kind of plays did not remain for a long time, as the classical plays began to be developed, where the art of acting based on the dialogue separated from the singing. Since the singing separated from the representative dialogue, it was natural for this dialogue to be developed moving towards the prose rather than the poetry. The art of theater changed continuously moving towards the realism, then the so-called modern drama emerged and the prose was taking its place, while the dramatic poetry was going down, as it is rare in the modern era to find the senior authors of the theater writing the poetic plays. 
The best European theater applies the classical rules is the theater of (Racine) and on the contrary, there were plays authored by (Corny) that had been attacked by the critics after the appearance of his play: (MR), which did not follow the classical rules.

Shakespeare the English author had a great influence on the romantic theater, even (Hugo) translated his plays into French and called to them. Then those plays began to spread among the writers and thinkers. Shakespeare was very famous in England and the other countries over two centuries, until he confessed to the people about his genius in the nineteenth century. (Hugo) had attacked the classical theater in the introduction of his novel (Kromopl)

The impact of Shakespeare on the European theater and writers, as they were affected by his subjects, and sometimes by his characters and emotions, and sometimes by his style, and sometimes by his technical template.

Besides the epic, lyrical and educational poetry there is the dramatic poetry. The word "drama" is derived from the Greek verb (Drao) and its meaning is: (works or moves), thus the literal derivative meaning of this term: (The dramatic poetry) is (kinetic poetry), i.e. the poetry that has the dialogue, along with the representative movement required on the stage. It is clear that the idiomatic meaning of the dramatic poetry is a theatrical poetry that is divided by the ancient Greek into two major types of dramas: (Tragedy) and (Comedy). The dramatic poetry called on: (Tragic and comic) but the word "drama" itself has been called today for the serious play to distinguish it from the comedy, i.e. "Laughing Theater" after the word (tragedy) disappeared, as the "tragedies" are not written with their old technical characteristics now. It is caused to be this word out of the technical term. In the modern era the "drama" is used for the plays that have Capricorn character, i.e. those dramas do not rely on provoking laughter nor as their target. (Note 1)

Art of the theater appeared in the ancient Greece within the confines of the old pagan religion, especially within the confines of the worship of god of the vineyard and wine, Dionysus, who was also called Bacchus. The farmers of Greek were organizing some rural festivals in the season of harvesting grapes singing the songs which contained the biography of God of the vineyard and wine to express their happiness and sorrow both that suggest the life of generosity when it is ripped and greened and is able to be plucked off, and then at the time of wither and dry leaves. These songs were written or purse in the form of the poetry along with the music and dance.

1. At first, someone sings the song, then it is repeated by the group called "chorus". The play dialogue starts in the form of exchange singing between the chorus and who leads the singers. The idea begins to grow until the poetic drama emerges in its final and integral image divided into the two great sorts that are known by: "The tragedy and comedy", which does not limit into the legend of the god Dionysus only, but its horizons begin to be widened and used as a means to embody all the other legends belonging to the gods and their conflicts or what is related to the gods and humans.

Although the characters of tragedy i.e. "The serious play" had been revolving, at first, around the gods only, but begun to include the legendary heroes of the humans, the kings and the princes as well.

2. Credit of this art goes to the ancient Greeks. Where the emergence of this art was in the fields, i.e. in the open air, away from the soothsayers and temples. Where it was able to live and grow. Where it began to be separated slowly from its first religious upbringing to include all aspects of life. Where it became a worldly civilian art as it was before a religious art originally. Even the comic drama took a deal with the problems of the public life, political and ethical affairs, and evolved to be a tool of the social, moral and political critique which can be able to reform, because the humans are afraid mostly to show 'laughter', therefore, the irony is a very sharp social weapon. (Note 2 )

3. The poetry of epics has passed its time through the impressive physical age, tournaments and faith to the supernatural physical events. Also, the dramatic poetry has begun receding since the eighteenth century to the present era, because the prose crawled the arts of various literature along with the creep of the realistic direction on all of the Arts and morals.

4. It is understood that the theater has become almost a mirror or a microscope to see the reality of life, as the poetic dialogue seems to be grandiose and artificial presentation in this art. As it seems that the prose has become appropriate for the nature of this art, as well as it is more compliant in the dialogue than the poetry. Therefore, the plays are not written in the poetry in the whole world except in a few rare cases that cannot be considered into the account. Most probably it will remain so, as long as the human has an emotional energy it must have a pot and outlet. 


\section{Inspiration from the Ancient Classical Literature}

The significance of this feature is that the term: Classical is also used to express the study of Latin and Greek literature (Classical Studies) and the reason for the use of the word in this concern Latin and Greek literature in the quality and subject.

Aristotle's theoretical assets are the gospel of classicism. As the great philosopher Aristotle did not address this in his book "Art of The Poetry" except the art of epics and drama, while he neglected to talk about the lyrical art, because he considered that it should be introduced into the musical literature. Most of his attention had gone to the theatrical literature in its branches: Tragedy and comedy more than to the art of epics, and all this, in addition to what he had written about the comedy did not reach us in the book: (Art of the poetry). The most of the assets of art that the classics had fought around were in fact the assets of art of drama in general, and art of tragedy in particular, so that the origins of classicism are found only in the theatrical literature, which is where the literature that all the effort of the classics went to and distinguished it, and still they are remembered by this virtue, while they are hardly mentioned in the poetry in the epics or the musical poetry.

The poets who appeared in the seventeenth century - when the origins of the classicism became clear and stabilized - we see them not only depart from the art of epics, but also the art of lyrical poetry to provide their efforts on the art of theatrical poetry in which they excelled and devoured the classicism by this poetry.

Although the classicalism was based on the simulation of ancient Greek and Roman literatures, following the artistic principles that guided these literatures with the inspiration of common sense, but that doctrine had characterized itself by some abstract artistic and human characteristics.

Technically classicism is concerned with the quality of language and the expressiveness of expression in no cost or verbal decoration. It is then that what is fully understood can be expressed clearly. Therefore, if the quality of the phrase is one of its origins, the clarity is its second origin. It is not permissible to consider this clarity as the facts recognized.

Since classicalism aims to express good articulation about the obvious meanings, it is natural that it depends on the conscious mind balanced at first, which inhibits the instincts and emotions, and controls them by the awareness of their hidden secrets and work. Classicalism is radiant with the light of reason, although it is true that the mind of classicism is not that cold thought that cannot enter into the literature, but is a hot mind in which the imagination, reflection and sensation meet in a balanced mood like the Attic mood that its owner is described that he thinks by his heart, feels by his mind and realizes by his imagination. French believe that the philosophy of Descartes reinforces the mind by calling to the clear and distinct ideas from the suspicion, which is considered by Descartes as the first principle of thinking, which begins with the first fact that the human mind realizes that he exists because he doubts i.e. thinks.

By the virtue of all these characteristics it was natural that the classicalism tends towards the objective literature. This type of literature is seen especially in the play or story.

It is possible that all the rules by which the classics bound the composition of the play belong to the origin of the general mind from which all the other rules are branched. This origin is the problem of life (vraisemblance), as the theater is the mirror of life or in the most correct word the microscope of life. Therefore, each play must represent a segment of life. As long as the play is presented in a specific time, they said that their problems of life require that they have what is called the three units, namely: The unity of the subject and unity of the time and unity of the place. Aristotle said that the first of them must be present in the play, while he considered the unit of time and place as a fleeting reference, because they both are the reasonable elements, but the classics made two narrow binding bases to them, and controlled the construction of the classic play by these two units. As such, the author is entitled to the unity of the subject, although this unit does not dissolve or dissipate with the secondary subjects, as long as they have a deep relation to the basic subject, and play a role in the evolution of the subject or in completing the portrayal of the characters and showing their psychological and moral facts. As the main theme is closed to the time and the place.

It is necessary to be mentioned that the romance led by (Victor Hugo) has mounted on these units a campaign in the name of the problem of life itself sometimes, and in the name of their own idea of theatrical art some other time. (Note 3)

\section{Divisions of Theatrical Art}

Classics inherited from ancient Greeks and Romans a precise division of the arts of theater, which they respect and adhere to. The arts of theater are divided into the tragedies and comedies, as each of them has its specific characteristics that should not overlap or combine them in the same play. Tragedy refers to the compassion and 
fear and cleans the human soul by them, and its style is the great highly, and its characters were taken from the kings and princes and noble persons, as well as they were to the ancients related to the gods and their fairness as well. Comedy is a comic play that makes to laugh for the entertainment or social and political criticism or to portray the psychological and social defects, and try to reform them. Although it was written in the form of poetry, but its language was often silenced, and its characters were often taken from the general public.

On this division, the classics marched through a series of tragedies and comedies, but this classical division had collapsed with the progress of humanity, growth of its culture and changing of its social conditions.

In the eighteenth century, the century of philosophy and social consciousness that paved the way for the Great French Revolution, we saw the writers and thinkers deny classicalism to limit the art of theater to the shocking tragedy and the mocking comedy, and later claim that it does not take a mirror or a microscope of life. These writers and thinkers said that the life in its general fabric is not a tragedy and not a comedy, because the people cry in the crises or giggle in occasional periods. The life is not black and not white, but it is in the most a gray thing, not to the extent of tragedy and weeping, and not to the extent of horrible laughing. So, as the play is not as tragedy as not to the extent of comedy, which depicts the life in its general fabric. This philosophical view ended to the emergence of a new type of plays called: Prince Drama, (Note 4) a drama that does not arouse a great sadness, nor a frightening panic, but just provoke the sorrow. As well as in the comedy that was ended by (Marivo) with a nice polite move that invented a special spirit in the comedy known by (Marivoudage) attributing to its owner. (Marivoudage) comedy alienated from the giggle, and rise from the baffling in laughter.

It can be said that people were not in a need to the sorrowful tragedies of the theater, nor were they prepared for the high hilarity, so the dramatic play and (Marivoudage) comedy was enough for them.

In the eighteenth century, the social conditions also began to be changed. The classical tragedy was limited to portray the tragedies of kings, princes and nobles, but the eighteenth century witnessed the growth of the bourgeois class, the middle class that ignited the great revolution that overthrew the king, princes and rulers. This class wanted the stage to present the problems of its life. The thinker (Diderot) felt the reality of this social development, when he called the bourgeois drama that chooses its subjects and personalities from the middle class. Thus this new type of plays emerged next to the tragedy and comedy, which had been limited to the art of the classical theater.

The bourgeois drama did not go only beyond the classical plays in terms of its subject and characters, but also came out in terms of the quality of the problems that were dealt by it. Classicism was only characterized by the general human problems. Its literature was called humanist literature, which deals with the tragedies of man as being the man himself depending on the theory of simulation: Simulation of the ancient Greek and Latin. The struggle in classical tragedies, for example, revolves around the humanity itself, such as the love, hatred, jealousy, abundance, reason, passion, emotions and feelings that are shared by all human beings and stem from the human nature.

Philosophers of the eighteenth century, especially Diderot who said that the human problems do not stem entirely from the nature of man, but that - if not the most - stem from the status of the individual in the society, and the social relations with the other individuals. The status of social figures or types of professions dealt by the authors in their plays is fertile material for the expression of human tragedy. This tragedy may affect the individual, not only because he is a human being, but because he is a doctor or a lawyer or a merchant or a farmer, as well as, a father or brother or brother-in-law. Indeed, Diderot himself put a bourgeois drama on this basis, which he called "The natural son", i.e. the illegitimate son, in which he portrayed his tragedy. Since then, the social seed had put in the whole literature.

However, the entire 18th century did not destroy the classicism, but it was instead a revolution and the attempt to destroy it or at least to break the rules and constraints that characterized the literature of plays appeared only in the nineteenth century with the emergence of romance-ism. (Note 5)

\section{Evolution of Classical Greek Theater to English Romantic Theaters}

Greeks were the first who took care of the theater and set a special system for it. The world took this art from them. Just as the theater started with the religious origin of Greece, as well as, to English.

Since the majority of the people at the time were illiterate, the men of the Church thought to bring the stories of Torah to their minds by placing them in the representative images. Here the representation of miracles begins in the history of literature, such as: (The killing of Abel and the birth of Christ and his crucifixion, Ibrahim's slaughter of his son, the flood of Noah, the day of reckoning and the news of the Christian saints... etc.). It was at the end of the twelfth and early thirteenth centuries. 
Then, some subjects related to the morality, such as justice, peace, truthfulness and lies were to the subject of these religious plays. Finally, the "congenital play" became independent from the miracle play when people could read the Bible themselves, and no longer needed to represent its stories to them.

The congenital play was a lesson in the ethics given by the representatives, and they represented moral things such as the sin, justice, honesty, lying, intelligence and stupidity.

The congenital play continued until the early 17th century, and then the people were tired from listening the moral advice and preaching, asking to address the problems of life and to see familiar characters. In the sixteenth century, a new type of play was created, which was represented in the ceremony of upper classes and banquet to fill the gap between two phases of the ceremony to entertain the audience and bring pleasure to theirs. It was a short play full of sources for the fun.

The first real independent theater was established close to London in 1576, and then English theater was rebuilt by Shakespeare (1564-1616).

European theater was influenced by Shakespeare. The play's writers were influenced by his subjects, sometimes by his people and his emotions, and sometimes by his artistic style.

\section{Theatrical Art in Modern Arabic Literature}

It is true that the art of acting and the art of theatrical literature was taken by Arabs from Europe after the Arab Renaissance that began in the last century. The pioneer of this art in the Arab world was Mārūn al-Naqqāsh. (Note 6)

Art of theater and the art of acting was not known in the Classical Arabic literature as it is known in the modern age, because the classical Arabic literature was a pure lyrical literature only or a literature of the messages and speeches. Although the Arabs had the knowledge of the intellectual effects of Greece, and the translation of Aristotle, but they did not try to follow the examples of Greeks in the representation and they did not translate anything from the plays of Greeks, because they were a pagan, and were against the monotheism to the Muslims.

Through the impact of the connection between the modern Arabic literature and Western literature a theatrical art appeared in Syria in the middle of the nineteenth century approximately. Then, the art of theater moved to Egypt in the late nineteenth century. It remained so even Ahmad Shawqi published his play (Death of Cleopatra) in 1929, which had no example in its popularity to the fans. It was the creation of a new stage in the play of modern Arabic literature. Then 'Abu Shādī and 'Azīz 'Abāẓa wrote some poetry plays. As well as Taymūr, Tawfìq al-Ḥakīm. Bishr Fāris, Ibrāhīm Ramzī, Maḥmūd Kāmil and the other also wrote a new theatrical literature. (Muhammad, K., \& 'Abd al-Mun'im Abū al-Futūḥ, p. 53).

Many of the writers in theatrical art, especially in Arabic literature, such as Yusrī 'Abd al- Ghan̄̄ 'Abd Allah wrote a book entitled "Arab Theatrical Art" in terms of its origin and development. He says that the theater started by the poetry, then it was written mostly in the prose, as it is known, and then evolved and became mostly written in the prose. Therefore, we see that the theater in the modern Arabic literature is divided into two parts: The poetic theater, i.e. theatrical poetry, and the prose theater. He divided the theater in modern Arabic literature into two parts: The poetic theater, i.e. Theatrical poetry, and the prose theater.

\subsection{Theatrical Art in Arabic Poetry}

The first poetic plays: (Conscience and Loyalty) that were written by Al-Yāzjī in 1870, tell about the King of Hīra Al-Nu'mān b. Al-Mundir, his misery and his bliss, and the Arab loyalty to Al-Nu'mān who offered to kill himself if he did not fulfill his covenant, but that play was weak in its language and artistic composition.

'Abu Khalil al-Qabbānī wrote several plays inspired by Islamic history. This is a step on the artistic path, but its style is a mixture of poetry and prose in the style of the (Standings) known by the name of (Maqāmāt) in old Arabic literature.

Hence, the attempts continued to achieve its artistic maturity, until the plays of Ahmad Shawqī appeared. It was the beginning of a new era in this field, such as: (Cleopatra's death), written in 1927 or 1929, then (The crazy man and Layla), then the play (Qambīz) in 1931, and then "Princess of Andalusia" in 1932, the same year in which he wrote his play ('Antara).

The last play of Shawqī was (Sitti Huda), but he died before its publishing, and has a play entitled (Bakhīla), which was published in the seventies of the twentieth century. 
All of Shawqi's plays are in the poetic form, with the exception of his play "Princess of Andalusia", which was written in the prose. All of his plays inspire their topics from the history, except the (Sitti Huda), which depicts a social theme of modern life.

It must be mentioned that Ahmad Shawqī in his plays was deeply influenced by the European theater, which he had seen during his educational trip to France. Despite this influence, Shawqī's theater was characterized by the Arab style, artistic plot and the appearance of clear features of the characters in many of his plays. Some critic say that Ahmad Shawqī wrote a dramatic poetry, but did not write a poetic theater.

Then 'Azīz 'Abāẓa, appeared after Shawqī and has plays including the (tree of the jewels), (Qais and Laila), ('Abbāsia), (Sunset of Andalusia) and (Al-Nāṣir) and the others... The dialogue in his plays has more motion and it is closer to the spirit of personalities.

Then some attempts appeared to write the poetic plays, such as 'Abd al-Rahmān al-Sharqāwi who wrote "A Beautiful Tragedy" in 1962, "The boy Mahrān" in 1966, "Husain as a martyr", "Husain is a revolting". There are some other plays written by Șalạ̣̄ 'Abd al-Ṣabbūr, such as (Laila and the crazy man), (Tragedy of Ḥallāj), (Princess is waiting) and the other plays.

Then a generation came, which had some creative efforts in the poetic theater, such as: Faruqe Juwaida who wrote (the lover minister), (Bloods on the cover of Ka'ba), (Khadivī), as well as, Anas Dawūd in the play (the poet) and (the fisherman). We have to mention here some other efforts were done by: Muhammad Ibrāhīm 'Abu Sinna, Mohamed Mahrān al-Sayyid, 'Abduh Badawī and the other Arab writers throughout the Arab world.

However, the writings of all these were influenced generally by the European, Americans and Russians writers. It is not an issue of surprising, because the impact and being influenced is a way followed by all the writers and literary persons.

\subsection{Theatrical Art in Arabic Prose}

Yusrī 'Abd al- Ghanī says that in ancient Arabic literature there is nothing known about the plays or the theatrical art, although there are some stories that have emerged in Arabic by the name: (Art of the standings) known by (AlMaqāmāt), but they do not depend on the theatrical art.

When the modern renaissance came into contact with the culture of the West and its fruits, the theatrical art was one of the most important literary creations. In the era of (Khadivii Ismail), the comedian theater and the old Egyptian opera house was established in 1869.

The first who introduced the theatrical art in the Arab countries was Mārūn Naqqāsh, from the Lebanese origin. When he traveled to Italy he quoted it in 1846. The first play he gave to the Lebanon Arab audience in 1847 was "The Scoundrel" by the French writer Molière.

However, this art was not initially welcomed or appreciated or encouraged, because the Arab public in Lebanon or in other Arab countries in general preferred singing, musical songs and humor. ('Abd Allah. Yusrī. \& 'Abd alGhan̄i, 2008).

\section{Theatrical Art in Modern Arabic Literature in Egypt}

A recent book entitled: The play -its development, history and origins- written by Dr. 'Umar Dusuqī. He says: The first Arab theater in Egypt was built by Jacob b. Șunu'a in Cairo in July 1876, which was also quoted from Italy, where he studied for three years. He was fluent in several languages that enabled him to study this art thoroughly. In the course of two years, he represented thirty-two plays adapted from Western literature that had a local color, and a topic that dealt with the social problems.

Khadivī Ismā̄îl encouraged him and impressed him on his seriousness in the development of plays, directing and acting, even he attended some of his plays and surnamed him Molière of Egypt.

He was encouraged by Ismail to form his band and to perform acting. He started his work in Alexandria and there he called his friend 'Adīb Ishāq to Alexandria to help him. 'Adāb had translated before the play "Andromak" by Rasin. When he came to Alexandria translated the play "Charlemagne". He was very impressed by the Egyptians and then participated with Salīm Al-Naqqāsh in the writing and acting of the plays.

One of those who translated the theatrical art into Arabic was Mohammed Othman Jalal who transferred from the French and add to his plays a pure Egyptian spirit. He was rightly called the father of national plays in the modern times.

The first play, which was written by Khalīl al-Yāzjī in 1786 in the form of poetry was (Conscience and Loyalty) and was represented on the Beirut Theater in 1888. Then Egyptian theater moved to a new stage after the arrival 
of Aḥmad Abu Khalil Qabbānī and his theater group from Damascus to Egypt in June 1884. Qabbānī depended mostly on the foreign plays Arabized. He tended towards the Arab-Islamic history and wrote some theatrical plays, such as: 'Antara, Prince Maḥmūd, son of Shah al-Ajam, Nakir al-Jumayyil, Ḥarūn al-Rashīd, Unās al-Jalīs, Nafạ̣ al-Ribī', Sheikh Waddah, and the others. His style in these plays was characterized by the finest language and closer to the classical Arabic, and he used the assonance and poetry together.

In this style, several plays were written in this period. Aḥmad Shawqī, was a student in Paris, he tried to write plays such as ('Ali Bik al-Kabīr), but did not show them to the public at that time, so it appeared later.

Yusrī 'Abd al- Ghanī says that the theatrical art is the father of expressive arts, but after the printing press, the reading became a popular profession available to all, so the novel and story, which was not so popular before began to spread. So the play had been written to be read. Then there was the cinema and television. They both are free from the theater in presenting the idea, as there is no need to go to the theater on specific days.

Egyptian theater enters the third stage by the transition to the social play. The new authors and the excellent actors were prepared for it. When White George 'Abyad came from Paris in 1910 after he studied the origins of acting on the hands of qualified professors. When Farah Anton published his novel: (Heliopolis and Ancient Egypt) that was presented by George 'Abyad in 1913, and then good plays continued dealing with the social problems.

This style of play was followed by Farah Anțūn Ibrāhīm Ramzī, where he composed plays such as: "The Ruler by the order of God", "The Nomad" and "The Heart of Woman". The theater also had a good band of actors who graduated from the Paris institutes or attended the same class such as 'Azīz 'Aid and 'Abd al-Rahmān Rushdī. The new theater had translated the best Western theaters, as the poet Khalīl Matrān translated the eternal plays of Shakespeare: Othello, Macbeth, Hamlet, and the Venetian merchant, but his translation was contradicted that translation was done by Alexander Qaldis and Kāmil Ḥunain, although the latter also quoted Shakespeare (Exiled prince) and (the twelfth night) and the others; as well as, Moliere plays were also translated well.

Yūsuf Wahbī opened the Ramses Theater on March 10, 1923, and it was a school that brought out many of the theater's heroes. It represented nearly 200 plays translated from the masterpieces of Western literature, and directed Egyptian plays from the heart of life in Egypt. The Ramses Theater suffered the hardships and obstacles and could not continue the struggle. Among the famous plays that appeared on the Ramses Theater in its early years are: "The Chair of Confession", "Slavery", "Madness" and "Ghāda Kamilia".

Another character who had an interest in the Egyptian play is the character of Najīb al-Raihānī. He was the prettiest among those who came to the theater stage in Egypt, although the language of his plays was mostly written by his colleague Badī‘ Khairī.

The Egyptian government had established the so-called national band, and invited the literary leaders to supervise them such as: Aḥmad Māhir, Mustafa Abdel Razzaq, Ṭāhā Husain, Tawfīq al-Ḥakīm and Khalīl Mațrān. It was expected from them to rise in the theater and feed it with the highest literature, as they had in their names a guarantee to attract the intellectual class of the theater, but it is clear that the people were the ones that finally prevailed and influenced by a certain color of plays in which humor, singing and a lot of arrogance is shown. However, there is still a theatre group struggling for the renaissance of the theater. For years, there was an institute of the theatre in which the origins and rules of the theatre were taught. It was supervised by Zaki Zalimat who had been connected with the theater since a long time and had an extensive experience.

When the modern Renaissance came and the Arab culture connected with the culture of the West, and its fruits were fruitful, the play was one of the literary forms that had a great interest. In the era of Khadivi Ismail, the comedy theater was established in 1869, and the old Egyptian opera house was established, where (Opera 'Âyida) was represented for the first time in the East for Italian Verdi.

\section{Conclusion}

After the First World War, a new theater appeared in the Arab theater world, which was concerned with theatrical composition. In the plays, it dealt with the social problems in a realistic way. Among the pioneers of this school was Muhammad Taimūr in his works: ('Abd al-Sattār Affandī), ('Aṣfūr in the Cage) and (The hell) and the others, but the French literature had a great impact on his plays.

Then the greatest writer of Arab theater Tawfiq al-Hakīm appeared who was closely related to the French literature, and presented the Arab play completed in its construction, theme, dialogue and personalities. His plays varied according to his different trends such as the historical, social, realistic and intellectual trends. He presented two plays: (O' Climber of the tree) and (Food for each mouth). They are from the irrational theater. The westerners took care of his plays and translated many of them to their languages. 
No one can deny the creative efforts done by several writers of Arab theater in the present era, which led to the diversity of the Arab theater in its directions and in its artistic construction. We can mention some of them here, such as: 'Ali Aḥmad Bakthir, Farīd Farrāj, Sa 'd al-Dīn Wahba, Yūsuf Idrīs, Maḥmūd Diyāb... and the others who had a clear impact on the advancement of the Arab theater.

Ancient Arabic literature did not know the art of play or the art of acting as it is in the modern era, but Arabic literature was purely a musical literature or literature of the messages and speeches. Although the Arabs knew the intellectual effects of Greece through their translations of Aristotle, but they did not try to follow the Greeks in their theatrical art, nor translate some of their plays, because they were pagan, and were contrary to the doctrine of monotheism among Muslims. (Muhammad, p. 53)

The theatrical art has passed through some stages before its maturity and equanimity. The first one was by Khalī al-Yāzjī, 'Abd Allah al-Bustānī and Muḥammad 'Abd al-Muțtalib. It was characterized by some naive and frivolous sometimes, and some dryness and poor perfection at other times. The second was by Ahmad Shawqi during the period of his studies in Paris (1887-1891). In this period he tried to address some issues in the framework of theatrical poetry, but was not able to get the success, as he did not receive the technical integrity to express the historical tragedies. Then he composed several powerful plays: Cleopatra's death, crazy of Layla, and 'Antara, and re-examined his play ('Ali Bik al-Kabīr and Qambīz). (Muḥammad, 2001, P. 107-108).

Shawqī in this Western art and his writing in it was a new breakthrough and a very important work, not only because it introduced this art for the first time in Arabic, but also because it resisted the stream of colloquial language that dominated the Egyptian theater and managed to distract the youth from it. (Shawqī, 1961, P. 80.).

So no doubt that the art of the play in Arabic literature was influenced by the European literatures in the first place, but it soon started to reach the stage of rooting and then the artistic creativity emerged, which was far from the imitation.

\section{References}

Muhammad, H. G. (1962). Comparative literature. Cairo: The Anglo-Egyptian Library. Third Edition. P. 376.

Aristotle. (1962). Art of Poetry 11449. B. Line: 24-25, (1962). Hilāl. Muhammad. Ghunaimī. Comparative Literature Cairo: The Anglo-Egyptian Library. p 160.

Sir Paul Harvey. (1989). The Oxford Companion to Classical Literature. produced by Oxford University Press. Words Dithyramb, Tragedy.

Muhammad, H. G. (1962). Comparative Literature. Cairo: The Anglo-Egyptian Library p. 161. Aristotle: Art of Poetry 11449. B. Line: 9-15.

Muḥammad, K., \& 'Abd al-Mun 'im Abū al-Futūḥ (No date). Studies in Comparative Literature, p: 53.

'Abd Allah. Yusrī. \& 'Abd al-Ghanī. (2008). Arab theatrical art - the emergence and development - Cairo.

Muhammad, K. (No date). Studies in Comparative Literature. p. 53.

Muḥammad, K. (2001). Studies in modern Arabic literature. Cairo: Al-Azhar University. P. 107-108.

Shawqī, D. (1961). Contemporary Arabic literature in Egypt. Cairo: Dār Al-Ma'arif. P. 80.

\section{Notes}

Note 1. Muḥammad, M. (No date). Literature and its arts. Cairo: Renaissance of Egypt. p. 59-60.

Note 2. Muhammad, M. (No date). Literature and its arts. Cairo: Renaissance of Egypt. p. 59-60.

Note 3. Muhammad, M. (No date). Literature and its arts. Cairo: Renaissance of Egypt. P.109.

Note 4. Muhammad, M. (No date). Literature and its arts. Cairo: Renaissance of Egypt. P. 119.

Note 5. Muhammad, S. S. (2005). Lectures in Comparative Literature. Jakarta: Solo Press. p. 100-107

Note 6. Muhammad, M. (No date). The Book of Theater. Cairo: Dar Al Ma'arif.

\section{Copyrights}

Copyright for this article is retained by the author(s), with first publication rights granted to the journal.

This is an open-access article distributed under the terms and conditions of the Creative Commons Attribution license (http://creativecommons.org/licenses/by/4.0/). 